\title{
LA CIUDAD Y LOS PERROS: TESTIMONIO DE UNA LECTURA Y OTROS SUCESOS COLATERALES
}

\author{
Óscar Hahn
}

Este artículo registra las primeras impresiones de Óscar Hahn durante su lectura de La ciudad y los perros de Mario Vargas Llosa, en 1963, y reflexiona acerca del empleo de distintas técnicas formales, como el uso del contrapunto y la anagnórisis, y de contenido, como la crítica a una sociedad racista, machista y violenta, regida por el canon del militarismo. Hahn combina el análisis literario con distintas experiencias reales vividas en un viaje de estudios a Lima, Perú, con sus alumnos de Arica, para visitar las locaciones de la novela, y sus encuentros personales con Mario Vargas Llosa, también en Arica.

Óscar Hahn (Chile, 1938). Miembro correspondiente de la Academia Chilena de la Lengua y Profesor Emérito de la Universidad de Iowa. Es Master of Arts por la Universidad de Iowa y Doctor en Filosofía por la Universidad de Maryland. En 1971 fue integrante del Taller Internacional de Escritores de la Universidad de Iowa. Algunos de sus libros de poesía son: Arte de morir, Mal de amor, Apariciones profanas y En un abrir y cerrar de ojos. Su obra más reciente es La primera oscuridad (2011). En 2009 sus poesías completas aparecieron en Madrid con el título de Archivo expiatorio. Ashes in Love, una edición bilingüe de sus poemas, fue impresa en Nueva York ese mismo año. Entre sus libros de crítica se cuentan: Fundadores del cuento fantástico hispanoamericano, Magias de la escritura y Vicente Huidobro o el atentado celeste. Sus poemas han recibido importantes reconocimientos y han sido traducidos a diversos idiomas. Acaba de recibir el Premio Iberoamericano de Poesía Pablo Neruda. Oscar-Hahn@uiowa.edu.

Estudios Públicos, 122 (otoño 2011). 
$\mathbf{E}_{\text {mpecé a leer La ciudad y los perros una tediosa tarde de }}$ 1963. En aquel tiempo vivía en Arica y estaba en cama, enfermo de no recuerdo qué. Nada grave por cierto. Un amigo mío que acababa de volver de Tacna me dijo: "Te traje esta novela. Es de un joven escritor peruano: Mario Vargas Llosa. No la he leído, pero me dicen que está muy bien". Me la pasó y se fue. A falta de otra cosa y bastante desganado tomé la novela. A Arica todavía no había llegado la televisión, así que las posibilidades de entretención para una persona que debía guardar cama eran pocas: o la radio o algún libro o revista. O la siesta para matar el tiempo, pero no tenía ganas de dormir. Tres de la tarde. Empecé a leer:

- Cuatro — dijo el Jaguar.

Los rostros se suavizaron en el resplandor vacilante que el globo de luz difundía por el recinto, a través de escasas partículas limpias de vidrio: el peligro había desaparecido para todos, salvo para Porfirio Cava. Los dados estaban quietos, marcaban tres y uno, su blancura contrastaba con el suelo sucio.

El Jaguar, Cava, el peligro. ¿Qué peligro? Más abajo viene la presentación de un tercer personaje:

— ¿Se acabó? ¿Puedo irme a dormir? — dijo Boa: un cuerpo y una voz desmesurados, un plumero de pelos grasientos que corona una cabeza prominente, un rostro diminuto de ojos hundidos por el sueño. Tenía la boca abierta, del labio inferior adelantado colgaba una hebra de tabaco.

Una descripción breve, certera, realista. "Vargas Llosa es el último realista", diría alguien, mucho después. Por esos años yo había leído Ficciones de Jorge Luis Borges, La invención de Morel de Adolfo Bioy Casares, Pedro Páramo de Juan Rulfo, Final del juego de Julio Cortázar y Guerra del tiempo de Alejo Carpentier, todos ellos bordeando o cayendo de plano en lo fantástico. Y ya se dejaba ver un incipiente realismo con apellido: el realismo mágico. Se suponía que el realismo a secas había muerto; que era cosa del pasado. De mágico o fantástico La ciudad y los perros no tenía nada. En el fondo es una novela del siglo XIX contada con técnicas del siglo XX, pensé. Hace poco, después de hacer un elogio de las grandes novelas del siglo XIX, el escritor norteamericano Jonathan Franzen dice: "La verdad, no creo que 
tenga que haber tanta polarización entre el realismo del siglo XIX y el modernismo del XX. Puedes tomar elementos de ambos y es así como describo mi proyecto literario". Esto ya lo había realizado Vargas Llosa casi medio siglo antes, en La ciudad y los perros. De la modernidad y sus secuelas el escritor peruano desestima esas piezas de museo que han llegado a ser el nouveau roman francés, la novela del lenguaje, la novela experimental, la llamada metanovela, y ni siquiera le atrae el objetivismo, que podría estar más cerca de un proyecto realista. Opta por lo más eficaz: elige técnicas narrativas multidimensionales, cercanas al cine, que le permiten representar con mayor riqueza el mundo que quiere poner frente a nuestros ojos.

Ahora entra un nuevo personaje: el cadete Alberto Fernández, conocido como el Poeta. Quiere salir unos días del colegio. Trata de convencer al teniente Huarina inventando excusas. Está obsesionado con ganar algunos soles. Escribe novelitas pornográficas y cartas de amor para que los cadetes se las envíen a sus novias. Una especie de Cyrano de Bergerac peruano, digamos. Aquí empieza el uso del monólogo interior, alternado con su diálogo con el teniente. Me gusta esta técnica. Le da rapidez y variedad al relato. Llego al episodio de La Perlita. Aunque me choca y a ratos me parece repulsivo, como la relación erótica entre Arana y el Enjendro, no tengo ninguna objeción que hacerle. Ni moral ni literaria. La moral de los personajes no es necesariamente la moral del lector. Lo único que se le puede exigir a un texto es "necesidad literaria". Y éste la tiene de sobra. Sería un gran error pensar que los personajes de una novela están condenados a regirse por la moral colectiva. O que el escritor tiene que escribir pensando en el qué dirán. Autor que hace eso está perdido, porque en el fondo significa someterse a la autocensura.

A medida que avanza la lectura siento que ésta es una novela de "machos". Lo prueba el simple hecho de que los personajes que uno recuerda, para bien o para mal, son todos hombres. Las mujeres son como epifenómenos de los varones. No es una limitación, porque lo que hace el autor es representar a la sociedad peruana tal como es, sin litotes ni mixtificaciones. Pero también se va desarrollando una morbosa paradoja. Vargas Llosa la exhibe y denuncia, no a través de exposiciones didáctico-morales, sino mediante un recurso típico del neorrealismo: deja que los hechos y los personajes hablen por sí solos. Por ejemplo, tomemos el culto a la hombría: "Y lo que importa en el Ejército es ser 
bien macho, tener huevos de acero", dice un oficial. Y sin embargo no tienen ningún problema, no sólo en involucrarse sino en jactarse de realizar acciones sexuales con otros cadetes del mismo sexo, llegando incluso a la violación. El capítulo en el que se describe de manera explícita el acto sexual con animales se entreteje con parlamentos como el siguiente:
¿Y qué tal si nos tiramos al gordito?, dijo el Rulos. ¿Quién? El de la novena, el gordito. ¿Tú no lo has pellizcado nunca? Uf. No está mala la idea, pero ¿se deja o no se deja? A mí me han dicho que Lañas se lo tira cuando está de guardia.

Sexo con un perro; sexo con gallinas; sexo entre cadetes varones, ¿quién puede saber la diferencia? Es la "bestia humana" que lucha por romper los barrotes de su jaula, diría Zola. Y, curiosamente, la descripción del episodio de La Perlita es bastante naturalista. Podría haber resultado anacrónica, pero es de gran fuerza narrativa.

Sigo leyendo. A estas alturas es como si hubiera dos novelas en una. Por una parte están los hechos que ocurren adentro del colegio militar (primera novela), y por otra, los sucesos del pasado y del presente, protagonizados por algunos cadetes, que se actualizan en diversos barrios de Lima, pero en los que participan personas que no tienen nada que ver con el Leoncio Prado (segunda novela). Se trata fundamentalmente de la relación entre ciertos alumnos y sus familias, y sobre todo de la presencia dominante, no por su carácter, sino como figura literaria, de una muchacha llamada Teresa y su vínculo con tres pretendientes distintos, uno de ellos innominado. Llama poderosamente la atención el rol de la figura paterna. Se puede dibujar un composite con los rasgos negativos del padre de Alberto y del Esclavo y surge un retrato bastante parecido al progenitor real de Vargas Llosa, según la imagen que él mismo ofrece en El pez en el agua y en el artículo "La sombra del padre", donde dice: "Tuve una relación desastrosa con mi padre, y los años que viví con él, entre los once y los dieciséis, fueron una verdadera pesadilla". El acercamiento de Alberto al teniente Gamboa es como si el joven anduviera buscando un substituto del padre que nunca tuvo y que le gustaría tener.

El novelista chileno Carlos Droguett dijo que la primera novela (llamémosla "A") es un relato de gran nivel, y la segunda (llamémosla "B") una novela rosa que no está a la altura de la otra. Discrepé de su 
opinión cuando la emitió (alrededor de 1963) y sigo discrepando más de cincuenta años después. Si aplicamos las directrices del género rosa, la novela "B" debería girar en torno a una sola pareja protagónica, brindarnos una satisfacción emocional y tener un final optimista. Además, los buenos deberían ser recompensados y los malos castigados. Nada de eso hay en la "novela B". Casi todo es emocionalmente insatisfactorio, y el desenlace o los desenlaces no son para nada idealistas. Tampoco ocurre la repartición maniquea de premios y castigos. En cierto modo, todos resultan castigados. Además, la estructura narrativa de la típica novela rosa es bastante elemental. En cambio la "novela B" tiene una estructura compleja: hay varias secuencias entreveradas. Lo que pasa es que la trama "B" parece más opaca, si la ponemos contra el telón de fondo que es la trama "A": tenebrosa y llena de tensiones a veces insoportables. Pero ambas están en una relación de interdependencia, como lo cóncavo y lo convexo.

A estas alturas ya he leído casi todo el libro y puedo comprobar una vez más que toda novela, cualquiera sea su tema o estructura, tiene elementos del género policial: hay un misterio que es necesario develar y hay pasos que se dan para develarlo; hay preguntas que se hacen y respuestas que se ensayan, y cadáveres reales o metafóricos que se intenta esconder en el clóset de la casa o del inconsciente. La ciudad y los perros no es una excepción. Los siguientes hechos podrían ser factores que configurarían cualquier novela de misterio clásica: 1) el robo del examen de Química; 2) el encubrimiento de los cadetes; 3) la investigación de las autoridades del colegio; 4) la delación de Arana; 5) el posible asesinato del delator; 6) la pregunta sobre el hechor: ¿quién mató a Ricardo Arana? La originalidad está en el punto 6. Ninguna novela policial podría darse el lujo de no ofrecer una respuesta segura, un desenlace cierto, porque el lector se sentiría defraudado y hasta estafado. $\mathrm{La}$ ciudad y los perros, en cambio, se atreve a dejar el enigma sin solución. Cuando en un coloquio sobre esta novela, organizado por la Casa de las Américas de Cuba, le preguntaron a Vargas Llosa si el Jaguar había matado a Arana, respondió que no sabía. En suma, lo que quiso decir fue: "En una novela los personajes y los hechos terminan por adquirir vida propia. El autor no tiene nada que agregar. Que cada uno saque sus propias conclusiones”. Veamos. ¿El Jaguar asesinó al Esclavo? Puede ser. ¿Fue sólo un accidente? Puede ser también. ¿El Jaguar lo mató y los autoridades del colegio están encubriendo el crimen? Es otra posibilidad. 
¿El hecho de que no lo juzguen demuestra que no hay pruebas contra él? Da que pensar, claro. ¿Caso cerrado o caso abierto?

Llego a la tercera parte. La encabeza un epígrafe que dice: "En cada linaje / el deterioro ejerce su dominio". Lo firma Carlos Germán Belli. Es la primera vez que veo este nombre. ¿Un poeta italiano, peruano, de algún otro país? No lo sé. Me pregunto: ¿Cuál es el linaje en el que estaba pensando Vargas Llosa? Sin duda el linaje militar, pero también la raza humana, supuestamente una, pero deteriorada por el racismo, la violencia, la falsa moral, la hipocresía, la mentira, el abuso de poder. Varios años después, todavía en Arica, recibo un libro de poemas que me llega desde Lima. Está dedicado y firmado por "Carlos Germán Belli". Tiene un curioso título que también podría haber sido epígrafe de la novela: El pie sobre el cuello. Los inescrupulosos, como el Jaguar, siempre le ponen el pie encima a alguien, y los débiles, como el Esclavo, siempre son los que ponen el cuello. Cuarenta años después, mientras escribo este testimonio, Carlos Germán Belli, que ahora es uno de mis mejores amigos, me envía su libro más reciente. Son sus poesías completas que llevan el título de Los versos juntos (1946-2008). Las encabeza un prólogo de Mario Vargas Llosa, que entre otras cosas dice: "El pesimismo que transpira la poesía de Carlos Germán Belli es histórico y metafísico a la vez. Tiene que ver con las condiciones sociales, que multiplican la injusticia, la desigualdad, los abusos y la frustración, y con la existencia misma, una condición que aboca al ser humano a un destino de dolor y fracaso". Estas mismas palabras, sin quitarles ni una coma, podrían aplicarse también a La ciudad y los perros.

Una de las estrategias narrativas que más me sorprendieron durante la lectura del libro fue el uso de lo que podríamos llamar "anagnórisis centrífuga". La anagnórisis clásica o reconocimiento, según aparece en la Poética de Aristóteles, es centrípeta. Se produce hacia adentro de la obra. Un personaje recibe información inesperada acerca de sí mismo y pasa de la dicha al infortunio. Esto último es lo que se llama "peripecia". En el Edipo rey de Sófocles, Edipo descubre que Yocasta es su madre, con todas las consecuencias que esa revelación desata. En la novela de Vargas Llosa no hay peripecia, y el reconocimiento ocurre afuera de la obra. La anagnórisis centrífuga no apunta al personaje, sino al lector real. Parte del texto y llega al receptor. El narrador habla continuamente acerca de un determinado personaje, pero omite u oculta el nombre con el cual se le conoce, dando la impresión de que se trata 
de dos personajes distintos. Hasta que en las últimas escenas el lector "reconoce" al innominado, no mediante señales o marcas como en la tragedia griega, sino porque ahora es nombrado explícitamente. Es lo que ocurre con el Jaguar. Esta técnica enriquece la configuración del personaje de una manera novedosa. El lector percibe primero al Jaguar como una figura unidimensional. No tiene pasado, no tiene historia, no tiene biografía. Básicamente, es el malo de la película que siempre piensa, siente y actúa de la misma manera. He aquí la opinión de uno de los cadetes: "No creo que exista el diablo, pero el Jaguar me hace dudar a veces". O: "El diablo debe tener la cara del Jaguar, su misma risa y, además, los cachos puntiagudos". Pero en los capítulos postreros el lector se entera de que no es así. Sin aviso previo, descubre que el otro, el sin nombre, el tercer pretendiente de Teresa, es el Jaguar en persona. De personaje esquemático pasa a ser, por acumulación retrospectiva de datos, una figura de dimensiones múltiples, que no excluyen ni el sentimentalismo ni la bondad.

Debo reconocer que me perturbó la virulencia de las alusiones racistas que hay en la novela. Nadie queda bien parado, ni siquiera los altaneros blancos, que despectivamente son llamados "blanquiñosos". De la gente de color se dice: "En los ojos se le vio que es un cobarde como todos los negros". Y el individuo que atiende La Perlita es apodado "el injerto", porque tiene "ojos rasgados de japonés, ancha jeta de negro, pómulos y mentón cobrizos de indio, pelos lacios". La voz cantante de la animosidad contra los serranos la lleva el Boa. Afirma sin tapujos: "Los serranos son bien hipócritas y en eso Cava era bien serrano. Mi hermano siempre dice: si quieres saber si un tipo es serrano, míralo a los ojos, verás que no aguanta y tuerce la vista". Y más adelante: "Cuídate siempre de los serranos, que son lo más traicionero que hay en el mundo. Nunca se te paran de frente, siempre hacen las cosas a la mala, por detrás". A lo que el Boa agrega:

Será por eso que los serranos siempre me han caído atravesados. Pero en el colegio había pocos, dos o tres. Y estaban acriollados. En cambio, cómo me chocó cuando entré aquí la cantidad de serranos. Son más que los costeños. Parece que se hubiera bajado toda la puna, ayacuchanos, puneños, ancashinos, cusqueños, huancaínos, carajo y son serranos completitos, como el serrano Cava. En la sección hay varios pero a él se le notaba más que nadie. ¡Qué pelos! No me explico cómo un hombre puede tener esos pelos tan tiesos. 
En asuntos altamente polémicos, siempre ha sido riesgoso dejar que los personajes emitan juicios de valor, y que el narrador en tercera persona, que el lector suele asociar con el autor real, se mantenga al margen. Hace unos días leí un foro en internet, en el que diversas personas debaten sobre La ciudad y los perros. Varias de ellas están convencidas de que los conceptos racistas que hay en la novela representan el punto de vista de Vargas Llosa. No comprenden que el escritor sólo transmite el estado de situación de la sociedad peruana, con respecto a las tensiones raciales. Pero el riesgo del malentendido es siempre un precio que los escritores honestos y temerarios como Vargas Llosa o Vladimir Nabokov (pienso en Lolita) han tenido que pagar. Uno es acusado de racista y el otro de pederasta.

En marzo de 1965 fui contratado como profesor en el Centro Universitario que la Universidad de Chile había establecido en Arica. Me pidieron que enseñara un curso de literatura hispanoamericana en la carrera de Pedagogía en Enseñanza Básica. En esos años la mayoría de los autores que después constituirían el llamado "boom” eran muy poco conocidos. Sin embargo, yo me iba enterando de las novedades, gracias a los libros que me hacía enviar desde Santiago mi amigo Pedro Lastra. Mi programa incluía a Borges, Rulfo, Carpentier, Cortázar, García Márquez (todavía no publicaba Cien años de soledad) y al joven escritor peruano Mario Vargas Llosa, autor de La ciudad y los perros, que de inmediato se transformó en libro de culto para los alumnos. Alberto, el Jaguar, el Esclavo, el Boa, el serrano Cava llegaron a ser prácticamente sus compañeros de clases. Hablaban de ellos como si fuera un grupo de amigos que los estuviera esperando en un bar para tomar una cerveza.

En octubre de ese mismo año iba a realizarse en Lima un partido definitorio para el Mundial de Fútbol de 1966: Chile versus Ecuador. Miles de chilenos se aprestaban a partir en toda clase de medios de transporte hacia la capital peruana. Un grupo de alumnos me propuso que emprendiéramos el viaje a Lima en dos autos, para asistir al partido. Después confesaron que en realidad lo que más les interesaba era visitar las locaciones que aparecen en La ciudad y los perros. Unos días antes del partido emprendimos el viaje a través de caminos polvorientos, sin pavimentar. Yo iba en el auto de Julio Torres, un alumno mayor que el resto. Nos acompañaban su esposa y dos alumnos más. Después de varias extenuantes horas de viaje por una carretera que, según creíamos, nos conduciría a Lima, nos cruzamos con varios autos que vienen en 
sentido contrario, ondeando banderas chilenas. Nos hacen señas por las ventanas y nos gritan que nos devolvamos. Se detiene uno de los autos y el conductor nos dice: "Este camino va a Arequipa, no a Lima." Dos horas de viaje perdidas. Nos devolvemos frustrados, pero sin perder el sentido del humor. “¿Arequipa? ¿No es ahí donde nació Vargas Llosa?”, dice uno de los alumnos. "Parece que este hombre nos pena".

Finalmente llegamos a nuestro destino. Después de instalarnos en el hotel, nos reunimos con los alumnos que venían en el segundo auto, a planear nuestro tour literario. "El barrio Miraflores no es un problema, porque aquí estamos", dice uno de ellos. "Tenemos poco tiempo, dice otro. Mejor vamos de plano al Callao, ahí está lo mejor: el Leoncio Prado y el jirón Huatica". "Claro, agrega un tercero, pero antes echémosle un vistazo a la estatua de Manco Cápac". Saca la novela y la abre. "Escuchen esto, lo tengo subrayado: 'Manco Cápac es un puto, con su dedo muestra el camino de Huatica'. ¿Se acuerdan de la Pies Dorados? Estaba en Huatica, ¿no?”. Abre el libro en otra parte y lee con voz de actor de radioteatro y exagerado tono sensual:

Alberto se desnudó, despacio, doblando su ropa pieza por pieza. Ella lo miraba sin emoción. Cuando Alberto estuvo desnudo, con un gesto desganado se arrastró de espaldas sobre el lecho y abrió la bata. Estaba desnuda, pero tenía un sostén rosado, algo caído, que dejaba ver el comienzo de los senos. "Era rubia de veras", pensó Alberto. Se dejó caer junto a ella, que rápidamente le pasó los brazos por la espalda y lo estrechó. Sintió que, bajo el suyo, el vientre de la mujer se movía, buscando una mejor adecuación, un enlace más justo. Luego las piernas de la mujer se elevaron, se doblaron en el aire, y él sintió que los pies se posaban suavemente sobre sus caderas, se detenían un momento, avanzaban hacia los riñones y luego comenzaban a bajar por sus nalgas y muslos, y a subir y a bajar lentamente. Poco después, las manos que se apoyaban en su espalda se sumaban a ese movimiento y recorrían su cuerpo de la cintura a los hombros, al mismo ritmo que los pies. La boca de la mujer estaba junto a su oído y escuchó algo, un murmullo bajito, un susurro y luego una blasfemia. Las manos y los pies se inmovilizaron.

— ¿Vamos a dormir una siesta o qué? —dijo ella.

—No te enojes, balbuceó Alberto- . No sé qué me pasa.

"Bueno, chiquillos", dice cerrando el libro, "Huatica nos espera, pero ojalá que no nos pase lo mismo que a Alberto". 
Llegamos al Callao y nos estacionamos en las inmediaciones del Colegio Leoncio Prado. Conseguimos la dirección exacta: avenida Costanera 1541. El edificio tiene una arquitectura curiosa. Al medio hay una especie de torre de cuatro pisos, flanqueada a ambos lados por una estructura de tres, la que a su vez tiene un par de alas de dos pisos. Nos acercamos a la reja principal. Al fondo se divisa la estatua del coronel Leoncio Prado. Según la historia peruana, este valeroso oficial arriesgó su vida por el Perú en varias ocasiones. Fue hecho prisionero por los chilenos y puesto en libertad con el compromiso de que depusiera las armas. Pero siguió combatiendo y fue hecho prisionero por segunda vez y condenado a muerte. Cuando iba a ser fusilado, él mismo dio la orden de disparar. Un modelo sólido, supuestamente esculpido en granito, pero que los cadetes de la novela hacían pedazos como si fuera de cristal. El propósito del colegio era modelarlos como pequeños clones del coronel Prado; el propósito de los jóvenes cadetes era parecerse lo menos posible a su modelo. En la novela, uno de los cadetes se refiere a él: "Le contaba que a los chilenos que lo fusilaron les dijo: 'Quiero comandar yo mismo el pelotón de fusilamiento"'. Y añade: "Qué tal, baboso".

Hablamos con uno de los guardias y le preguntamos si podemos visitar el recinto. "Somos chilenos. Hemos viajado desde Arica especialmente para conocer el Colegio Leoncio Prado". Muy amablemente nos dice que no se puede. Que si antes hubiéramos enviado una carta pidiendo permiso, a lo mejor nos habrían autorizado. "Lo siento mucho, jóvenes". Nos alejamos bastante decepcionados, pero después de todo, hemos estado ahí, frente al legendario colegio militar. Y es aquí donde la realidad y la ficción no se dan la mano. Desde afuera, el recinto nos parece demasiado cotidiano, demasiado de este mundo; en la novela, en cambio, es el espacio pesadillesco de una temporada en el purgatorio.

$\mathrm{Al}$ día siguiente regresamos con el fin de visitar el pecador jirón Huatica. Siguiendo el libreto de la novela, dejamos a los alumnos, todos varones, en la esquina de 28 de Julio y Huatica. "En una hora más los pasamos a buscar en esta misma esquina", les dice la esposa de Julio a los alumnos que vienen con nosotros. "Ah, y avísenles a los del otro auto". "Y, por favor, no vayan a hacer alguna estupidez con esas mujeres", grita, asomando medio cuerpo por la ventana.

A las once en punto de la noche llegamos al lugar convenido. Los dos estudiantes se suben al auto. No parecen muy contentos. "Fue un desastre", dice uno de ellos. "Es la peor experiencia que he tenido 
en mi vida". "Hay una especie de cité, con una fila de cuartos que dan a la calle. Frente a cada puerta había varias colas, algunas de dos o tres hombres, y otras de unos ocho o más. Entraba un tipo, no estaba ni diez minutos adentro, salía y entraba el siguiente, y así en adelante. Superdeprimente". "Lo que a mí más me impresionó", dijo el otro, "fueron los papeles. Al lado de cada puerta había un cerro de hojas de papel higénico arrugadas".

Casi medio siglo después de haber leído la novela, mi memoria aún retiene algunas escenas que el tiempo no ha desvaído. Recuerdo varias, pero son dos las que prevalecen de manera indeleble y por razones distintas. La primera es el monólogo interior del Boa durante la ceremonia de degradación del serrano Cava. La segunda es la escena del bar, cuando Alberto decide llamar por teléfono al teniente Gamboa para denunciar al posible asesino de Ricardo Arana.

Como sabemos, "perros" es la denominación despectiva que reciben los cadetes de tercer año y de grados inferiores. La escena a la que me voy a referir tiene que ver con esos "perros", pero principalmente con una perra de verdad, con un animal que se llama Malpapeada. Aquí queda claro que Vargas Llosa es un maestro en la técnica del contrapunto, que consiste en combinar dos líneas de acción paralelamente, como se hace en la música con dos o más melodías. En la escena que nos interesa, una de esas líneas es la ceremonia ritual para expulsar a Cava. La otra es el inocente jugueteo de la Malpapeada con los cordones de los zapatos del Boa, que está cuadrado militarmente, mientras observa la humillación del serrano. La primera línea es tensa y dramática. La segunda tiene otro propósito. Al hablarle mentalmente a la perra juguetona, el Boa puede disimular la fuerte emoción que lo embarga y evitar que los oficiales se den cuenta de los sentimientos de compasión que está experimentando, indignos de un duro militar.

Un contrapunto diferente, mucho más complejo y más difícil de materializar, es el que lleva a cabo Vargas Llosa en la escena del bar y que tiene a Alberto Fernández como protagonista. Alberto está llamando por teléfono al teniente Gamboa. Transcribo la escena completa:

Marca el número y escucha la llamada: un silencio, un espasmo sonoro, un silencio. Echa un vistazo alrededor. Alguien en una esquina del bar, brinda por una mujer: otros contestan y repiten un nombre. La campanilla del teléfono sigue llamando con intervalos idénticos. “¿Quién es?”, dice una voz. Queda 
mudo; su garganta es un trozo de hielo. La sombra blanca que está al frente se mueve, se aproxima. "El teniente Gamboa, por favor", dice Alberto. "Whisky americano", dice la sombra, "whisky de mierda. Whisky inglés, buen whisky". "Un momento", dice la voz. "Voy a llamarlo". Tras él, el hombre que brindaba, ha iniciado un discurso. "Se llama Leticia y no me da vergüenza decir que la quiero, muchachos. Casarse es algo serio. Pero yo la quiero y por eso me caso con la chola, muchachos". "Whisky", insiste la sombra. "Scotch. Buen whisky. Escocés, inglés, da lo mismo. No americano, sino escocés o inglés". "Aló", escucha. Siente un estremecimiento y separa ligeramente el auricular de su cara. "Sín", dice el teniente Gamboa. "¿Quién es?” "Se acabó la jarana para siempre muchachos. En adelante, hombre serio a más no poder. Y a trabajar duro para tener contenta a la chola”. "“” ¿Teniente Gamboa?", pregunta Alberto. "Pisco Montesierpe", afirma la sombra, "mal pisco Pisco Motocachy, buen pisco". "Yo soy. ¿Quién habla?" "Un cadete", responde Alberto. "Un cadete de quinto año". "Viva mi chola y vivan mis amigos". "¿Qué quiere?" "El mejor pisco del mundo, a mi entender", asegura la sombra. Pero rectifica: "O uno de los mejores, señor. Pisco Motocachy". "Su nombre", dice Gamboa. "Tendré diez hijos. Todos hombres. Para ponerles el nombre de cada uno de mis amigos, muchachos. El mío a ninguno, sólo los nombres de ustedes". "A Arana lo mataron", dice Alberto. "Yo sé quien fue. ¿Puedo ir a su casa?". "Su nombre”, dice Gamboa. "¿Quiere usted matar a una ballena? Déle pisco Motocachy, señor." "Cadete Alberto Fernández, mi teniente. Primera sección. ¿Puedo ir?" "Venga inmediatamente”, dice Gamboa. "Calle Bolognesi 327." Alberto cuelga.

La literatura siempre ha tenido que enfrentar el problema que plantea el carácter lineal del lenguaje, es decir, el hecho de que las imágenes y los conceptos contenidos en las palabras se vayan presentando unos tras otros, de manera sucesiva, lo que dificulta la representación de la simultaneidad. En la realidad o en el cine, si dos personas hablan al mismo tiempo, el receptor puede escuchar razonablemente bien los parlamentos paralelos. Pero cómo mantener la simultaneidad cuando se trata de discursos expuestos en un continuum verbal. Es difícil lograrlo, pero no imposible, como lo prueba la escena antes citada. En este episodio hay un entramado de cinco voces que se escuchan, ya sea una tras otra en rápida sucesión, o incluso simultáneamente: la del narrador om- 
nisciente, la de Alberto (monólogo interior y diálogo), la de la persona que contesta su llamada, la de un parroquiano del bar y la de Gamboa, también a través del teléfono. Un deficiente manejo técnico podría redundar en que el lector se confunda y no sepa quién o quiénes están hablando, pero Vargas Llosa resuelve este desafío con admirable pericia. Me he referido al aspecto formal, pero también está el contenido de lo que se habla. Lo que dice el parroquiano sobre sus planes matrimoniales está dirigido a los amigos que lo escuchan, cosa que al lector le interesa poco o nada. La única función de esta línea del contrapunto es mantener el suspenso. En cambio la otra línea, lo que dice Alberto, más que apelar a Gamboa, tiene como destinatario al lector de la novela, porque le crea expectativas con respecto al enigma que lo mantiene en vilo: el posible asesinato de Arana.

1969. Recibo inesperadamente la visita de Enrique Lihn. Anda de paso por Arica. Me cuenta que va a un encuentro de escritores en Arequipa y que tiene que tomar un avión en la ciudad de Tacna. El problema es que se le ha perdido el pasaporte. Le digo que no se preocupe, que lo solucionaremos rápidamente, porque el cónsul de Chile en Tacna es un escritor: Benjamín Subercaseaux. Conseguido el pasaporte de reemplazo, yo mismo llevo a Enrique al aeropuerto. Estamos esperando que llegue el avión en el que debe embarcarse, cuando notamos que decenas de personas, cámaras y libretas en mano, obviamente periodistas, inundan el recinto. Aterriza el avión, se abre la puerta y aparece el mismísimo autor de La ciudad y los perros, acompañado de Patricia, su mujer. Un poco más atrás vienen Jorge Edwards y Pilar Fernández de Castro. Apenas Vargas Llosa entra en la sala de espera y divisa a Enrique, se aproxima a él haciendo caso omiso de los periodistas que lo acosan, y lo abraza con su afabilidad de siempre. Yo me he mantenido discretamente al margen, hasta que Enrique, dirigiéndose a Vargas Llosa, le dice: "Quiero presentarte al poeta Óscar Hahn. ¿Le puedes conceder unos minutos antes de que te rapten los periodistas?" "Por supuesto que sí", contesta extendiéndome la mano. Le digo que quiero invitarlo a Arica a dar una charla. "Y a usted también, por supuesto", agrego, mirando a Jorge Edwards. "No sé si podrían". "A mí me encantaría", dice Vargas Llosa, "pero en vez de una charla preferiría tener un diálogo con los alumnos y responder sus preguntas". "Me parece bien,", digo. "Lo único es que no tenemos ni un centavo para pagarles. Yo los puedo venir a buscar para llevarlos a Arica y podemos alojarlos a todos en un 
muy buen hotel, pero no nos alcanza para honorarios". "No te preocupes", dice Vargas Llosa, "vamos así no más. Pero con una condición. Que me lleves a conocer el Morro de Arica". Para un peruano, visitar el lugar donde se había librado una de los combates emblemáticos de la Guerra del Pacífico es una necesidad existencial. Más aún para Patricia Llosa, uno de cuyos antepasados había participado en la contienda.

Al día siguiente vuelvo a buscarlos. Él va en el auto, sentado al lado mío. En esos años había publicado sólo dos novelas: La ciudad y los perros y La casa verde, pero ya era el benjamín del boom. Le pregunto si está trabajando en otra novela. Me dice que se dedica a reunir información sobre un curioso plan del Ejército peruano para llevar grupos de prostitutas llamadas "visitadoras", a una guarnición de la Amazonía. Confiesa que tiene problemas con el título del futuro libro. "Una posibilidad, dice, sería ponerle el nombre del protagonista". En este punto yo ya había tomado confianza, así que me animo a decirle: "Quizás podría ser simplemente Las visitadoras". "Bueno", dice él, "Lo que está claro es que la palabra "visitadoras' tiene que aparecer en el título".

El coloquio con Vargas Llosa, en el que también participa Jorge Edwards, se realiza en el salón de actos de la sede. Hay unas trescientas personas, en su mayoría universitarios de izquierda, que acuden a ver a uno de los suyos. Lo recuerdo con mucha nitidez, porque ocurrió un incidente que nadie habría anticipado. Uno de los estudiantes le pregunta acerca de una entrevista en la que Vargas Llosa habría declarado que él no era incondicional de ningún régimen. Hasta ese momento Vargas Llosa era un conocido partidario de la revolución cubana, viajaba frecuentemente a La Habana y era miembro del consejo de redacción de la revista Casa de las Américas. Buscando quizás que hiciera una excepción, el alumno insiste: “¿Eso incluye a la revolución cubana?”. Todos esperan que Vargas Llosa diga algo así como "bueno, se trata de una situación distinta". Pero ante el estupor de los presentes responde con firmeza: "Lo dije y lo repito. No soy incondicional de ningún régimen, incluida la revolución cubana". Y agrega algunas palabras cuya letra no recuerdo exactamente, pero cuyo espíritu es el mismo de su discurso de recepción del Premio Rómulo Gallegos, otorgado a La casa verde ese mismo año: "La razón de ser del escritor es la protesta, la contradicción y la crítica. La literatura es una forma de insurrección permanente y ella no admite camisas de fuerza. Todas las tentativas destinadas a doblegar su naturaleza airada, díscola, fracasarán. La literatura puede morir, pero 
no será nunca conformista". Lo desconcertante es que estas palabras, que antes de la pregunta del estudiante habrían sido vistas como dirigidas a las sociedades capitalistas, ahora parecen un inesperado golpe al mentón del gobierno cubano. Para que se entienda el impacto que causó su declaración, no hay que perder de vista que fue hecha dos años antes de la ruptura rotunda y definitiva de Vargas Llosa con el régimen castrista, a raíz del caso Padilla.

Al día siguiente Jorge Edwards se marchó con unos amigos, Patricia y Pilar se fueron de compras, y Vargas Llosa se quedó conmigo en el lobby del hotel. "Vamos al centro a tomar un algo", me dice. Estuvimos un par de horas en un café de la calle 21 de Mayo. Recuerdo que hablamos de Borges y que en un momento se puso a recitar de memoria los primeros párrafos del cuento "Los teólogos". Cosa que me pareció sorprendente, porque el tipo de narrativa que escribe Vargas Llosa tiene poco o nada que ver con lo que hace Borges, pero demuestra que es capaz de admirar propuestas completamente distintas a las suyas. No quise preguntarle sobre La ciudad y los perros. Por alguna razón misteriosa, preferí que la novela permaneciera intacta en mi imaginación. Quizás temía que si procesaba los datos algo se haría trizas en mi mente. Tampoco me atraía saber quiénes eran los modelos reales en los que se había basado para diseñar a sus personajes. Sabía, eso sí, que él había sido cadete del Leoncio Prado entre los 14 y los 15 años. Mucho tiempo después leí que para el personaje del Jaguar se había inspirado en un alumno de apellido Bolognesi, bisnieto del coronel Francisco Bolognesi, que había muerto combatiendo en la batalla del Morro de Arica, en 1879. Curiosa coincidencia: el Morro de Arica es el mismo lugar que Vargas Llosa me había pedido visitar cuando lo conocí en el aeropuerto de Tacna. La información sobre el origen del Jaguar, en vez de enriquecer mi percepción del personaje, no hizo más que confirmarme una cosa: que el joven Bolognesi era una persona y el Jaguar otra, y que en mi mente el personaje ficticio había terminado siendo mucho más real que el supuesto modelo.

La crítica ha dicho que Alberto Fernández, el Poeta, es Mario Vargas Llosa, pero el mismo escritor, en el prólogo a ediciones posteriores de la novela, reveló algunas cosas. Contó que había empezado a escribir La ciudad y los perros en Madrid, en el otoño de 1958, y que la había terminado en París en el invierno de 1961. Y añade: "Para inventar su historia, debí primero ser, de niño, algo de Alberto y del 
Jaguar, del serrano Cava y del Esclavo, cadete del Colegio Militar Leoncio Prado, miraflorino del Barrio Alegre y vecino de La Perla en el Callao". Con esta declaración el mito de que "el Cadete Alberto es Vargas Llosa", queda desacreditado. No se trataría entonces de un yo real, representado por un solo yo ficticio, sino de un "yo plural", por usar la expresión de Borges, refractado en varios personajes novelescos. En el mismo prólogo Vargas Llosa dice algo más que merece ser comentado: "Y debí de adolescente, haber leído muchos libros de aventuras, creído en la tesis de Sartre sobre literatura comprometida, devorado las novelas de Malraux y admirado sin límite a los novelistas norteamericanos de la generación perdida, a todos, pero, más que a todos, a Faulkner. Con esas cosas está amasado el barro de mi primera novela, más algo de fantasía, ilusiones juveniles y disciplina flaubertiana". La suma de las dos declaraciones citadas, aunque Vargas Llosa las aplica específicamente a La ciudad y los perros, en el fondo es el vademécum de la novela como género. La materia con la que se crea cualquier novela es una amalgama de la realidad vivida, las lecturas del autor, una determinada idea de la literatura, la puesta en marcha de la imaginación y el trabajo incansable del escritor.

Desde esos lejanos días de 1969 me he reunido con Vargas Llosa varias veces, en Estados Unidos, Perú y España. La más reciente fue en octubre de 2009, en Madrid. Jorge Edwards se encontraba allí de paso y me llamó al hotel para decirme que Mario nos esperaba en su casa. Antes de ir compré La ciudad y los perros. Tenía la primera edición dedicada por él, pero se la presté a una polola de esos años y nunca me la devolvió. De la conversación en su casa lo que mejor recuerdo es un diálogo muy enriquecedor con él y con Jorge Edwards sobre Victor Hugo. Como en otras ocasiones, hablamos de su visita a Arica. Me sorprende la cantidad de detalles que aún conserva en la memoria, a pesar del tiempo transcurrido. Mencionó que en esa ocasión fuimos a una librería, porque él andaba buscando algún libro, cualquier libro, de Juan Carlos Onetti, y que encontramos una antología de cuentos titulada $E l$ infierno tan temido. "Mira tú, dice él, lo que son las cosas, y varias décadas después escribí ese libro sobre Onetti". Le pido que me dedique el ejemplar de La ciudad y los perros que he llevado. Tiene un prólogo suyo que dice en las últimas líneas: "Este es el libro que más sorpresas me ha deparado y gracias al cual comencé a sentir que se hacía realidad el sueño que alentaba desde el pantalón corto: llegar a ser algún día es- 
critor". Han pasado cuarenta años desde que nos vimos por primera vez en Arica, y ahora, qué duda cabe de que su sueño se ha cumplido con creces. Salimos de la casa de Vargas Llosa a la noche madrileña. "Gran escritor y gran persona", dice Jorge Edwards mientras caminamos. "Así es", digo yo. "Ojalá que algún día le den el Premio Nobel". 